\title{
Creating Indigenous Discourse: History, Power, and Imperialism in Academia, Palestinian Case
}

\author{
Janette Habashi \\ The University of Oklahoma
}

\begin{abstract}
This article examines the impossibilities of implementing decolonizing research for indigenous scholars. In addition, it articulates the relationship between a decolonizing research approach and the historical and current forms of academic imperialism; a prototype of the Palestinian legacy is presented. The author argues that the current indigenous discourse is a remnant of oppression. The existing indigenous discourse is not due to the original quest but instead, it is in response to oppression. Also, the author explains the struggles of some indigenous scholars in complying with the reporting and ownership of knowledge that is required by Cartesian principles.
\end{abstract}

Keywords: indigenous discourse; academic imperialism

Decolonizing research has been articulated as a new line of thinking in academia. This project initiative provides space and legitimacy to the contribution of indigenous discourse. The approach was primarily produced as a result of postmodern and postcolonial thinking. Traditionally, during the enlightenment and colonization period, indigenous scholars had to eliminate prior knowledge and espouse colonial discourse. As a result, decolonizing research challenges dominant modern methods of knowing and reinforces indigenous identity and discourse. Elaborating on indigenous knowledge invites questions on the appropriateness of adopting modern paradigms in understanding the indigenous journey (Smith, 1999). Semali and Kincheloe (1999) and Taiaiake (1999) have presented ample perspectives on the issue of integrating indigenous discourse and how it is important to embrace the challenges of such an endeavor. Indigenous discourse resists alien paradigms and uses a native method of knowing. The foundation of decolonizing research is the empowerment of subordinate narratives that challenge Western ways of meaning/understanding as well as the views of non-Eurocentric studies. However, this article argues that in reality, decolonizing methodology creates

Qualitative Inquiry, Volume 11 Number 5, 2005 771-788

DOI: $10.1177 / 1077800405276809$

(C) 2005 Sage Publications 
an imaginary supremacy of an alternative research methodology that is very much seeded in traditional Western episteme.

The purpose of this article is to understand the controversial relationship between the contemporary concept of decolonizing research and academic imperialism using the Palestinian people as an example. Some may question how one could decolonize research if the scholar is colonized. The concern is not the methodology of decolonizing research but rather, the impossibility of decolonizing research for a community that has frequently been subjugated and muted. The issue of indigenous research versus Western research, although explored extensively, nevertheless requires a new analytic lens. This article explores the question of whether decolonizing methodology is a genuine epistemic innovation or if it is an extension of colonized discourse. Using the Palestinian experience as a prototype, data from this legacy are presented to examine this question. Such a question is a challenge, especially because oppression has been for so long a daily reality (Carey, 2001; Farsoun \& Zacharia, 1997; Finkelstein, 2003; Pappe, 1992). Palestinian oppression is defined here as resulting in not only the collective mass displacement and transfer of the population in 1948 and 1967 but also the incessant and invisible effort of muting (silencing) the Palestinian narrative.

The impossibility of decolonizing research for genuine indigenous studies becomes more problematic when critiquing indigenous discourse within decolonizing research because the author is an indigenous researcher from a culture with a well-established history of scholarship. When the fundamental claim for decolonizing research is to empower indigenous discourse, its intention is questionable, especially when some indigenous scholars are experiencing colonization. A difficult road lies ahead when not only the reader expects final resolution but also the individual becomes the owner of the collective knowledge. The issue of indigenous discourse becomes more complicated by the Cartesian view, which values the individual over the group. It is important to note that the voice of the individual in this article is not the focus; rather, the voice is a means of conveying a collective knowledge and does not claim ownership or final representation of such knowledge.

In Western academic heritage, scholars and academic institutions glorify the individual over the group and ignore the extensive connections between the individual and the collective. An illustrative example of the misunderstanding that develops between collectivist and Cartesian discourse is demonstrated by a recent experience of the Guatemalan scholar Rigoberta Menchù. Menchù (1996) expressed that the collective experience was part of her suffering. In response, Western scholars attacked Menchù because they claimed she had not personally experienced these calamities (McLaren \& Pinkney-Pastrana, 2000). The converse of this argument is that the individual is part of the collective voice and, on the other hand, nominates oneself to be the spokesperson of the group. This paradox is part of the inherent oppression in which the role of the individual and the group are inconsistent. Confu- 
sion declines when we consider the indigenous scholars' agency rights according to their geopolitical culture and do not evaluate scholars according to Cartesian principles. Agency rights to geopolitical culture emerge when the individual is a member of the collective and has responsibility toward the group. Such a perception of agency does not register in Western academic institutions that perpetuate imperialistic principles or in decolonizing research attempts because the Cartesian notion is the foundation and the extension of imperialistic values.

The shared expressions in these pages are rooted and articulated within the political upheaval and social injustice that the current Palestinian generation and previous generations have endured. Therefore, the reflections are not those of the author; rather, they are the understanding of the Palestinian people. The reason for taking such a stance is to empower the collective and to treat the individual as a member who is connected and committed to the community cause. The approach makes it necessary to situate both the author and the reader. This article works to produce a statement in which the reader locates the author; on the other hand, the article highlights the author's location. The stand I take is one of collective reasoning rather than one of individuality. Therefore, I invite the reader to look at the article from the collective mentality.

\section{A REVIEW OF THE LITERATURE AND STATEMENT OF THE PROBLEM}

The current effort of promoting decolonized research to challenge mainstream discourse is not the first attempt in the history of higher education; rather, it is a consistent recurrence of Eurocentric academic trends that perpetuate what is known as "academic imperialism" (Churchill, 1995). Such epistemology is in response to the universal ontology that is preset by Eurocentric claims and manifested in education, morals, priorities, women's issues, and so forth. Some scholars disagree and claim that ample attempts have been made to challenge the dominant way of knowledge, such as in feminism and indigenous and critical studies. The premises of these studies are to enforce alternative tools of research so they will be accepted into the domain paradigms. However, the blueprint of academic imperialism relies on a single dominant pedagogy to reproduce intellectual discourse. Presenting the views of non-Western scholars does not indicate deviation from the orthodoxy of academic imperialism. It is only reinforcing epistemology that coincides with its values (Barkan, 1994).

Postmodern and postcolonial social science studies and resulting theories provide evidence for the existence of academic imperialism (Hill, McLaren, Cole, \& Rikowski, 2002). It is often argued that the work of decolonizing research is an academic myth, especially when methodological parameters 
are designed within existing cultural and academic traditions. Churchill (2000) stated, "The monolithic White Studies configuration of U.S. higher education ... thus serves to underpin the hegemony of white supremacism in its other, more literal manifestations: economic, political, military and so on" (p. 54). The preeminent configuration in higher education institutions does not allow research conditions to flourish that are incongruent with the prevailing Western academic tradition. Therefore, no matter how much methodological reconstruction is done in decolonizing research, one cannot have a meaningful account of indigenous contexts without acknowledging the historical and current hegemony of European influence on modern academe.

It is difficult to make connections between academic endeavor and cultural imperialism because the prevailing conception is that academia occupies a "neutral role" or is "value neutral" (Churchill, 1995; Said, 1994). Academic neutrality is a false argument because academic endeavor is constituted in time and processes that intersect with cultural and academic imperialism (Churchill, 1995; McLaren \& Pinkney-Pastrana, 2000). The existence and practice of such a relationship (in terms of valued topics, funding research, research methods, etc.) hinders the establishment of a context that is conducive to genuine decolonizing research, particularly from an indigenous perspective. Some indigenous and feminists scholars are working hard to change the situation, but their voices are not heard.

The concept of decolonization implies that scholars from formerly colonized nations are now free from oppressive conditions and have the academic freedom to produce, implement, or reconstruct cultural discourses. It is ironic that within this context, the concept of decolonizing research is produced from former as well as current imperialistic academic institutions (Greeson, 1994; Hiner, 1978, 1990). The expectations of "ex-colonialist nations" have not changed in higher academic institutions (Churchill, 1995); they are simply disguised under new slogans of liberalism and openness. The subtle association between neocolonialist governments and their academic institutions has never been precisely researched; therefore, little is expressed about colonized discourse and its role in contemporary neocolonialist research.

The proponents of decolonizing research base their premise on changing the power structure in academia (Mutua \& Swadener, 2003; Smith, 1999). The objective is noble and the notion of reconstructing the power structure governing research is essential for understanding the impact of colonization. However, two major problems become apparent concerning these attempts. First, mere deliberation about hegemony does not necessarily provide an instrument for or an outcome of decolonizing research. Consideration does not empower non-Western scholars, particularly when academic institutions continue to act as the guardians of imperialistic values (Barkan, 1994; Churchill, 1995; Hiner, 1990). The second problem in decolonizing research is the construction of the term non-Western. The term defines an existence by a negation rather than an affirmation. The term is popular in higher education and 
describes "indigenous" scholarly work. The supposition is that Western thinking is the standard and non-Western thinking is dependent, less dignified, and academically inferior to the Western paradigm. Although some nonWestern scholars accept the superiority of Western research standards, indigenous people reject the entire premise.

Steve Biko, a prominent South African political activist, rejected the term non-White to describe the Black indigenous people of South Africa:

They would no longer use the term non-Whites, nor allow it to be used as a description of them. They were being stated as "non something" which implied that a standard was something and they were not of that particular standard. (Arnold, 1978, p. 14)

Although Biko was not arguing with Western academy, his point is significant in the context of this article for understanding the construction of academic slogans. To empower non-Western research, indigenous scholars should also refuse to be called non-Western researchers. Being called non-Western implies that the researcher accepts the supremacy of Western methodologies, standards, and paradigms. To make the case worse, a diversity of knowledge is lumped under the terms Western and non-Western; therefore, new ways to describe such knowledge need to be considered because not all non-Western discourses come from the same school of thought and/or experience. Although considerable work has been done in reconstructing to eliminate attachment to Western knowledge and the term non-Western, such as in indigenous and aboriginal studies, still the work is identified as non-Western discourse.

To better understand how decolonizing research for indigenous scholars is a myth, I outline a conceptual framework and historical context and present a brief case of Palestine as an illustrative example. The following section provides a framework for the discussion of decolonized research by examining the concepts of oppression, indigenous consciousness, and academic discourse. The next part of the article places indigenous discourse within a historical context. Finally, I examine the case of the Palestinian context.

\section{Oppression, Indigenous Consciousness, and Academic Discourse}

Historical examples reflect the intersection between oppression, indigenous political consciousness, and academic discourse. The most significant examples of such articulations are the historiographic works of Biko (as cited in Arnold, 1978), Fanon (1965, 1967), Freire (1997), and Memmi (1965). Although the backgrounds of these testimonials are different in location, time, and ethnicity, their works are imperative for highlighting the paradoxical reality and consciousness of oppressed people and how their perceptions 
of subjugation are impediments to progress toward freedom. Fanon belonged to the colonialist nation France, but he acted in contrast to national interest. Biko was the founder of the South Africa Student Organization, Memmi was a Jewish Arab scholar in Tunisia, and Freire was a Brazilian revolutionary. Their works attempt to identify oppressive situations and to note the complexities endured by oppressed people who went through an assimilation process and simultaneously resisted their oppressors. The challenge was to break the sting of oppression and transform the oppressed mentality. These testimonies are exclusive particularly when situating oneself in the collective struggle. Participating in meaningful engagement in resistance and maintaining the integrity of those being oppressed certainly shed some light on those looking in as well as those portraying an outward image of oppression (Bhahba, 1998; Gibson, 1999).

Biko, Fanon, Freire, and Memmi pinpointed the mental processes and psychological exertions associated with oppression. Fanon (1967), in his book Black Skin White Masks, exposed the contradictions that are associated with assimilation, where the uprooting of individuality and collective identity is the expected behavioral outcome. Biko (as cited in Arnold, 1978) articulated the nuances of behavior associated with society's attempts at integration:

It is an integration in which Blacks will compete with Blacks, using each other as stepping stones up a steep ladder leading them to White values. It is an integration in which Black man will have to prove himself in terms of these values before meriting acceptance and ultimate assimilation. It is an integration in which the poor will grow poorer and the rich richer in a country where the poor have always been Blacks. (p. xviii)

Psychological distortion is the key to sustaining continual dominance over subordinated groups because it creates internal oppression among the subjugated individuals. Reflecting on subjugated and paradoxical realities and their psychological distortions leads to the understanding of a "mind-set" concept and its role in discourse development. "Mind-set" represents the shared experiences of those who are oppressed and the oppressors who superimpose specific thought processes on the dialectic. The resulting intellectual activities only empower the oppressor's manifestations and further limit the possibility of any power substitution. The subject matter is the perpetuation of oppression even if national liberation occurs. The oppressed continue to execute the implementations of the oppressors even though the very principles were once wholeheartedly resisted. A concern that is repeatedly emphasized is how such mental conditioning implicitly restricts oppressed people from true liberation. The notion is that once free, oppressed people continue to be locked into oppressivelike patterns. A quandary emerges because the oppressed people have to face not only the consequences of oppression but also the tendency to continue the cycle of 
oppression (Bhabha, 1998). Such is the legacy of colonization that continues for generations.

The answer for this vicious cycle and "mind-set" lies not in the spectrum of oppression alone but in the economic status of the society as well as in intellectual and social resistance. Within the subjectivity of assimilation as well as resistance, oppression may fluctuate depending on the societal fabric of the intellectual elite and the bourgeois liberals. Such groups are committed to national resource availability, including labor provided by the working class. The bourgeois liberal and intellectual elite always play a significant role in reproducing the "mind-set" and perpetuating oppression. Interior oppression restricts the transformation of "mind-set," and these liberal elitist groups are the major beneficiaries of such discourse. Elaborating on the extent of the oppressed "mind-set," therefore, reflects the limitations of the collective reference and cultural discourse of the oppressed people. Hence, some individuals are radical social agents for transformation as Biko, Freire, and Fanon demonstrated.

The limitations of oppressed cultural discourse evolve from years of colonization. People are denied the fundamentals of cultural integrity by means of containment or solitary confinement. After being oppressed, the conquered are denied the right to practice their indigenous religion, and missionary campaigns act vigorously to convert people to accept another's faith. ${ }^{1}$ The conquered are also denied the right to speak their native language and are forced to communicate in a foreign language (Bridges, 2000; Churchill, 1999). New colonial methods of social and economic structures are additional mechanisms for eradicating existing culture. The purpose of new structures is to normalize and humanize the indigenous from their assumed subhuman state and to meet the normative level of their colonialist counterparts. Although Biko and other activists recognized the objectives of the colonizers' practices, including strategies for psychological distraction, the result was the eradication of cultural discourse.

Biko, along with other activists, focused on the perpetuation of oppression and why oppressed people cannot overcome the oppression following their "independence." The authors analyzed the characteristics of the perpetuating strategies of oppression, which helped explain the limitations of trying to salvage cultural discourse within the continuous materialization of oppression.

\section{Historical Context of Creating Indigenous Discourse}

To understand oppression and indigenous discourse, it is essential to consider their history and relationship to academic institutions. Earlier in this article, an explanation for the development of indigenous discourse was 
offered. It is essential, however, to examine the continuance of colonial dominance in different academic schools of thought. It should be noted that this article neither suggests a magic formula that would break the cycle of the oppressed "mind-set" nor advocates that decolonizing research is a means of reconnecting with indigenous discourse; rather, the purpose is to enunciate the issues that lead to the conclusion that decolonizing research is a modern academic myth.

The understanding of the mythical proportion of decolonizing research rests on the familiarity of colonizing discourse as it appears within the epistemology of imperialism (Churchill, 1999; Lacsamana, 1998; Said, 1993) as well as in the postmodern and postcolonial notions of Gandhi (1998) and Spivak (1999). A current trend among economically powerful countries is to enforce imperialistic principles in academic institutions (McLaren \& PinkneyPastrana, 2000; Said, 1978; “The Fight Over 'Patriotic Correctness,'” 2002); nonetheless, some scholars relentlessly resist government and political pressure. Such individuals act in defiance, isolating themselves from dominant political views of government and engaging in providing insight on alternative political stands. Interactions of neocolonization intersect deeply with globalized perceptions of indigenous discourse. The composition and practice of global life encourages each nation-state to follow the lead of the global market policy. Global policy persistently disrupts cultural self-image such that people have little opportunity to salvage their cultural heritage (Bridges, 2000; McLaren \& Farahmandpur, 2001).

Rescuing indigenous heritage was a concern of social scientists in colonial eras. Colonial theories of human development create the idea that globally, individuals must comply with a universal definition of personal growth, including current needs and future prospects (Cannella, 1996; Grieeshaber \& Cannella, 2001; James \& Prout, 1997). The imposition of universal development not only crossed cultural barriers but colored the understanding of historical narratives and indigenous discourse as well. All cultural groups and their individual members had to comply with an imposed knowledge structure. Cultures unable to submit conclusively to imposed ideology provided evidence to confirm their inherent backwardness. Any manifestation of resistance to imposed discourse was indicative of immaturity and refusal to accept the enlightenment. Acting in accordance with colonist theories was a gesture of agreement with the prevailing power structure and an acknowledgment of superiority of the colonists' discourse. Equality within competing discourses was out of the question because truth for the colonizers lay in the recitation of power and superiority according to a prescribed script. Implication of the colonialist intellectual model was necessary for success and became manifested in pedagogies and intellectual processes.

Postmodern theories do not contradict the imposed power structure and, therefore, allow the continuation of colonial dominance (Hill et al., 2002). Some postmodern perspectives were built on the ashes of colonial views, yet 
they fundamentally never disturbed the colonialist agenda. Indigenous voices were cited in postmodern discourse; however, the power discourse never changed, thus, leaving the indigenous to continually be the Other. Postmodernism did not alter the power structure; rather, it enforced the colonial stereotypic assumption about indigenous discourse. Scholars espoused the postmodern paradigm on the ground that it provided an avenue to speak out. However, the result was the maintenance of the colonial power structure because the configuration of postmodern paradigms was built on the foundation of an imposed cultural discourse with the assumption that changing contextual names resulted in a transformation of praxis.

The irony lies not only in postmodern theories but in postcolonial assumptions as well. The postcolonial mantra is that previously colonized countries are now free of outside control (Bartovich \& Lazarus, 2002; Chrisman \& Parry, 2000; Gandhi, 1998; Spivak, 1999). On the contrary, circumstances are created whereby imperialistic interests are served even when physical colonization is not apparent, a process Parenti (1988) described as the "practice of direct exploitation without the burden of direct rule" (p. 66). Oppressed people have only one escape, but the choice relies heavily on the prevailing imperialistic discourse (McLaren \& Pinkney-Pastrana, 2000). The opportunity to restructure a discourse is consistently conditioned by an imperialist or colonialist approach. Therefore, indigenous people have no alternative-were they to succeed-but to adopt the intellectual imposition of the neocolonialist academy. Although support exists for resisting this approach, the dissenting voices are rarely heard. Choices for decolonization research conducted within the framework of a neocolonialist equation are not a liberating concept because both insiders and outsiders operate within an oppressive culture where imperialism is a widespread phenomenon.

In postcolonial projects, academics have insisted on integrating remaining pieces of indigenous discourse to enhance the assumption of culturally appropriate practice (Barkan, 1994; Gandhi, 1998). Combining postcolonial theories with fragments of indigenous discourse is delusional. The collaborative hybrid contrasts with the common materialistic experiences of the indigenous and their historical oppression resulting in a significant dispensing of some individuals' activities. Interpreting the accounts of individual activity does not correspond to the historical reasoning of a given tradition; rather, it is a process that denies the systemic pattern of collective subordination and focuses on the remnants of tradition but is void of any understanding of its historical context (Lacsamana, 1998).

Traditional discourse developed purposefully. Picking and choosing remnants from traditional ritual does not reflect the historical quest of the discourse. Such practices only perpetuate confusion. Current indigenous discourse is the result of oppression experience and is not a response to an original cultural journey or quest. 
Oppression recklessly eliminates the composition and foundation of indigenous discourse. Contemporary discourse addresses only those issues that concern current cultural materialism. Therefore, the timing of the decolonizing research claim is fundamental: It could be perceived as one "liberal academic body" treating the Other in an old/new oppressive regime in the guise of intellectual property. The colonial perception of indigenous culture and discourse are classified as explicitly exotic (Said, 1978); colonized cultures are treated as entertainment entities that require the endorsement of the colonists (Bahl, 1997). Hence, the postcolonial continues the colonial notion but with a new twist for rescuing indigenous discourse. The context of feminist writings of the globalized North (Western culture) is an example. The attempt was to colonize southern women's discourse in the name of "freedom for all women" from patriarchal exploitation as perceived by women from the globalized North. The act of liberating the Other, in this case women, is as exploitative as colonization. Literature enforces the continuing legacy that the globalized South needs to be "humanized" and that the appropriate incentive is the globalized North's perception of humanity:

I would like to suggest that the feminist writing I analyzed here is discursively colonizing material. ... I argue that the assumptions of the privilege and ethnocentric universality on the one hand, and inadequate self-consciousness about the effect of the western scholarship on the "third world" in the context of a world system dominated by the west on the other. (Mohanty, 1994, p. 197)

Attempts at postcolonial intervention mislead both readers and indigenous people. Therefore, the interpretations of postmodern and postcolonial theories should be rejected.

\section{Remains of Indigenous Discourse and Neocolonialism: The Case of Palestine}

Colonial hegemony destabilizes cultural development and uproots indigenous discourse from its original composition. The remains of the discourse are a mere reflection of the reality of oppression and not the authentic collective reference. For example, Palestinian discourse has been tremendously interrupted by Zionist colonization. Palestinian discourse was fundamentally disrupted when $80 \%$ of the land was colonized in 1948 and the indigenous people were forcibly displaced (Khalidi, 1992; Pappe, 1992). Consequently, relationships between the land, art, and original geopolitical discourse were altered to fit a harsh new reality.

Palestinians living in the diaspora number 3.5 million, and most of them are refugees. Eighty percent of the Palestinians in the Gaza Strip and $40 \%$ of those in the West Bank are refugees. Twenty percent of the Palestinians living in Israel face discrimination based on age-old European racism (Firer, 1998; 
Ram,2000; Soen, 2002). Palestinians in all geopolitical locations are denied the opportunity to learn about their history. The Palestinians who are living in Israel have to learn the ideology of Zionism, and the curriculum does not refer to Palestinian populations that were living on the land before the establishment of Israel in 1948 (Al-Haj, 1998; Gur-Ze'ev, 2000). The curriculum perpetuates the assumption that it is "a land without people and people without land." This was the rumor that was spread to the Jewish communities around the world in the beginning of the 20th century to encourage individuals to settle in Palestine. The case for the Palestinians living in the West Bank and Gaza Strip is different; before 1993, Palestinians living in the West Bank had to take on the Jordanian curriculum and in Gaza, Palestinians had to adopt an Egyptian curriculum (Parry, 1995). However, both curricula were reviewed and modified by the Israeli Security Office. The effect was the elimination of any statements that might imply Palestine or Palestinians. The current curriculum designed by the Palestinian Authority is reviewed by the Israeli government, which has the prerogative to enforce or delete any unit (Asaad, 2000). The new curriculum does not teach Palestinian legacy because it is not in line with the "Peace Process." Ironically, the Israeli government does not follow the same process. Israeli curricula continue to deny the history of Palestinian people who inhabited the land before the establishment of the Israeli state in 1948. Palestinians living in Israel have to learn the history of Zionism without any reference to their own history. Consequently, current Palestinian discourse does not mirror the roots and chronological complexities of original indigenous discourse such as child rearing, communication, land usage, ownership, religion, and education.

The application of decolonizing research to current Palestinian reality is an act of academic imperialism. This is so because it excludes the history of oppression and attempts to salvage remnants of cultural discourse on behalf of the indigenous. In this process, little reflection on the complexity of oppression endured by the indigenous population is attempted. Even if precolonized indigenous discourse is examined, it cannot be used because it is historical and does not mirror current geopolitical circumstances. Nonetheless, remains of indigenous discourse are created to comply with contemporary imperialistic imposition. The decolonizing approach is not applicable to the Palestinian people because the Palestinian political situation has not changed since 1948. Indigenous discourse, however, has changed tremendously since Zionist colonization; therefore, indigenous discourse cannot be treated as an entity separate from the oppressive situation. Geopolitical realities prohibit the introduction of such a notion. However, one could argue that this approach might be significant for another reason. The question in this case is whether the indigenous society is free from colonization or colonization has changed to globalization.

Ignoring Palestinian reality is a colonialist power perception. Colonialist discourse refuses to account for Palestinian rhetoric but enhances the muting 
of historical narrative. Drawing from this preconceived assumption, academic imperialism (within its language structure) is a power composition because it consciously avoids addressing the historical realities of oppression. Indeed, roots and history prevail in indigenous narratives; history is part of the future and such understandings are not ubiquitous in the globalized North. Indigenous cultures simply yearn for their history and the time when imperialism was not part of their experience, and they also look to the future when imperialism will no longer be the preference. As a result, academic institutions in the globalized North fail to reflect on the process of indigenous discourse because imperialistic values do not encompass reflectivity about oppression and it consequences.

\section{The Struggles of Indigenous Scholars}

Discussing the relationship between academic imperialism and indigenous discourse does not lead to an understanding of oppression if the paradoxical reality of the indigenous scholar is omitted. Complexity evolves from interactions among academic imperialism, oppression, and the day-to-day struggles of indigenous researchers. Struggles occur when endorsing neocolonialist methods while ignoring the historical context of indigenous discourse. The question is in the methods that are contingent on the historical context. Time is an important variable in the discourse process. The assumption is that indigenous scholars must be sanctioned by liberal academics and receive permission to express their perspectives. The discursive sphere of oppression, therefore, is not only perpetuated by the oppressed but also conditioned by the representation of the oppressors in specific forms.

Presentations of indigenous discourse are constituted within the framework of "liberal" notions. A different challenge emerges in the reluctance toward, and ambiguity of, self-criticism in neoliberal thinking. The substantive issue in this case is regarding the Other as a separate entity. What can liberals learn from the Other discourse remnants, for example, without first fully understanding the historical spectrum of academic imperialistic praxis? This framework of inquiry, designed by "liberal academics/neocolonists," manipulates indigenous discourse and encourages the continuation of academic imperialism. In addition, an assumption is implied regarding the notion of Others that their history is rooted in indigenous discourse as well as in familiarity with colonial perspectives. This assumption fails to reflect on the interaction between both discourses. It is apparent that decolonizing research denotes an attitude similar to the colonial structure associated with the Other; in other words, it is now possible to enclose indigenous discourse (remains) with little reflection on exclusive political and academic practices and their relationship to academic imperialism. Decolonizing research, in this context, is a disingenuous call that results from a lack of self-criticism by the global- 
ized North and its role in promoting academic imperialism. A new account should be based on academic self-criticism and its implication for indigenous discourse.

Documenting the impact of colonization on changing the process of the discursive sphere is essential to successfully expose the original conditions of cultural discourse design. Neocolonial intellectual and materialistic activities should not be disregarded when considering current indigenous discourse. Oppression limits discourse and alters the direction of collective reference; therefore, rather than continuous discourse delivery, only discursive pockets occur in most cases. Making sense of the confusion is no longer the goal. What is important is to be aware of the relationship between the individual and the collective and their relationship to discourse. Current pockets of discourse are not designed solely within the indigenous articulation but merely within the persistence of oppression. Nonetheless, continuous indigenous effort is being made to maintain a collective identity that is influenced by current oppression dilemmas. The matrix is far from complete, but it becomes more systematic when options are unveiled to which indigenous researchers acquiesce.

A predominant struggle for the indigenous scholar is the contradiction between acting as an individual in the academy and acting as a member of the academy. Each choice has a different connotation. Intellectual property, as well as discourse, is part of indigenous culture and belongs to the collective, not to the individual. When reporting indigenous narratives to the globalized Northern academy, the language is no longer based on collective knowledge but on individual endeavor. The globalized Northern academic language, however, is not founded on the same knowledge construction values. Therefore, some indigenous scholars struggle with academic reporting. The knowledge construction of indigenous cultures is a collective property: It is generated from the collective experience. Within a collective cultural context, individual success cannot be claimed because the creation of knowledge is not founded on individual liberty; cultural discourse always belongs to the group of which the individual is a member.

Some indigenous scholars are academically torn when negotiating between collective discourse and individual reporting that intends to claim ownership of the collective intellect. The tradition among globalized Northern scholars is to declare individual accomplishment that is enforced through academia's traditional values of competition, individualism, and ownership. Claiming individual ownership for collective knowledge becomes a paradox for the indigenous scholar as well as another myth of decolonizing research.

Indigenous scholars face imperishable questions when studying cultural issues. Individual ownership, cultural representation, language, and the reconstruction of intellect strongly prevail. Complexity in reporting is only part of the political position a researcher encounters (Churchill, 1995; McLaren \& Pinkney-Pastrana, 2000; Memmi, 1965). Failure to establish a 
political stance on what seems an objective study deludes the researcher in attempting to understand the complexity of the academy and the academy's response to indigenous research.

\section{CONCLUSION}

The primary objective of this article is not to find a method to decolonize research but to articulate the impossibilities for such an intention. The prevalent reason for decolonizing research is in the method of academic imperialism. Academic imperialist discourse is entrenched in academic methodology, language, and ontology. Questions raised in this article include, Is there an indigenous discourse for the Palestinian situation? and Is decolonizing research a genuine endeavor? In essence, the purpose of the article was not to provide answers to these questions; rather, the intent was to offer an overview of the complexities of decolonizing research for both Palestinian people and anyone who endures oppression. Another issue that emerges is whether current research alternatives, which are part of the discourse, are intertwined with the historical context of colonization. A problem remains about some indigenous and Western scholars' blindness to the reality of geopolitical and academic culture. Alternatives, in this situation, are accessed only within the globalized Northern perspective that is already ingrained in the colonialist praxis.

The innovation of decolonizing research comes from the same framework that uprooted the indigenous method for lexicalizing discourse. The current problem lies not only in the historical limitation of cultural discourse but also in the continuing perpetuation of imperialism by local scholars in the globalized South. A method used to cement the legacy of colonization is to persistently empower the intellectual elite of the globalized South, who played a significant part in perpetuating strategies of oppression. The intellectual elite may struggle in the process of trying to preserve their individual status and their collective interest, but such are the means of espousing the colonized approach. Elite groups relentlessly adopt the colonialist method of lexicalizing discourse and avoiding critiques. Intellectual elites play a significant role by associating with the globalized North and also neglecting selfreflection of their role in perpetuating oppression and enhancing the continuation of academic imperialism. Therefore, it is essential to disrupt the notion of decolonizing research, in particular for Palestinian people and for other scholars who might perceive themselves as colonized. As I mentioned before, the primary purpose of this article is not to look for solutions but to pinpoint the paradoxes that indigenous scholars endure. It is too simplistic to wait for a solution; however, highlighting the obstacles demands more insight than one might recognize. The more we preview the paradoxes, the more we under- 
stand the challenges. Therefore, I invite the reader to look at and understand the situation as part of the solution, not as a separate entity.

The irony is that Western academics expect indigenous scholars to propose a process to solve the problem statement. I believe the case here is no different. I was asked to dictate a solution to this complex academic reality; however, this might contradict the premises of this article. During my writing of this article, I intentionally avoided proposing a solution not because I was unaware of the existence of such a request but because the recommendation of an answer is another example of Western thinking. This request was not unanticipated, because most Westerners do not experience what I am articulating. Although they show some empathy, in reality, they are at the other end of the oppression spectrum. In addition, the Western academy is by design looking for a disclosure. It seems that having the opportunity for disclosure equates, in a way, to having options. However, from the oppressed standpoint, we do not have the luxury of such a prospect; rather, we strive to survive an oppressing reality. The act of surviving and sustaining as a collective is partly our solution. The reality of oppression does not allow oppressed people the opportunity for disclosure. Encouraging indigenous scholars to search for a solution is part of a colonialist ideology that maintains the illusion that we have choices and power. Therefore, any proposed research alternative from other oppressed scholars or myself is deeply intersected with colonial discourse-as it is well articulated in this article. This constrains our options, which to begin with are the result of a contemporary-historical imbalance in structures of power and privilege. In other words, we do not have the choice to form an alternative discourse. The choices are prefigured in the boundaries of colonialist discourse. Hence, we need to look back to history and learn from historiographic accounts from examples such as Becko, Fanon, and Freire. These testimonies lead me to restate these discourses of resistance and education as part of the solution. We need to remember that even resisting discourse is not an option; it is prohibited by the paradigm of imperialism.

Retaining the essence of the article, I would like to invite the reader-especially now that you have a greater understanding of the paradoxes of indigenous discourse - to propose an answer, if there is such a thing, for the Palestinian reality as well as for other geopolitical communities that find themselves the object of the same calculus of academic imperialism. The reader is here reminded that economic and political globalization is another form of imperialism and colonization. Creating a collective understanding and, therefore, a dialogue is more powerful than anything other scholars or I might propose. In addition, collective understanding will assist us as scholars to challenge the delusion of Cartesian views, particularly in indigenous work. I encourage the reader to submit his or her view to this journal in an effort to challenge the article and to be constructive in articulating a new research methodology. 


\section{NOTE}

1. In 2000, the Pope apologized for Catholic acts during periods of colonization, especially to those people who were forced to change their spiritual beliefs.

\section{REFERENCES}

Al-Haj, M. (1998). Arab education: Development versus control. In Y. Iram \& M. Schmida (Eds.), The educational system in Israel (pp. 91-111). London: Greenwood.

Arnold, M. (Ed.). (1978). Steve Biko: Black consciousness in South Africa. New York: Random House.

Asaad, D. (2000). Palestinian educational philosophy between past and present. Studies in Philosophy and Education, 19, 387-403.

Bahl, V. (1997). Cultural imperialism and women's movements: Thinking globally. Gender and History, 9(1), 1-14.

Barkan, E. (1994). Post-anti-colonial histories: Representing the other in the imperial Britain. Journal of British Studies, 33, 180-203.

Bartovich, C., \& Lazarus, N. (2002). Marxism, modernity and postcolonial studies. Cambridge, UK: Cambridge University Press.

Bhabha, H. (1998). Remembering Fanon: Self, psyche and the colonial condition. In K. Williams \& L. Chrisman (Eds.), Colonial discourse and post-colonial theory: A reader (pp. 112-125). New York: Columbia University Press.

Bridges, R. (2000). Imperialism, decolonization and Africa. New York: St Martin's.

Cannella, G. (1996). Deconstructing early childhood education: Social justice and revolution. New York: Peter Lang.

Carey, R. (Ed.) (2001). The new intifada: Resisting Israeli apartheid. New York: Verso.

Chrisman, L., \& Parry, N. (2000). Postcolonial theory and criticism. Woodbridge, MA: Brewer.

Churchill, W. (1995). White studies: The intellectual imperialism of U.S higher education. In S. Jackson \& J. Solís (Eds.), Beyond comfort zones in multiculturalism: Confronting the politics of privilege (pp. 17-37). London: Bergin \& Garvey.

Churchill, W. (1999). The crucible of American Indian identity: Native tradition versus colonial imposition in postconquest North America. In D. Champagne (Ed.), Contemporary Native American cultural issues (pp. 39-65). London: AltaMira Press.

Churchill, W. (2000). White studies: The intellectual imperialism of contemporary U.S. higher education. In E. M. Duarte \& S. Smith (Eds.), Foundational perspectives in multicultural education (pp. 50-68). New York: Longman.

Fanon, F. (1965). The wretched of the earth (C. Farrington, Trans.). New York: Grove.

Fanon, F. (1967). Black skin White masks (C. L. Markmann, Trans.). New York: Grove.

Farsoun, S., \& Zacharia, C. (1997). Palestine and the Palestinians. Boulder, CO: Westview.

The fight over "patriotic correctness" in the universities. (2002, February 24). Revolutionary Worker, (1140), p. 13.

Finkelstein, N. (2003). Image and reality of the Israel-Palestine conflict (2nd ed.). London: Verso.

Firer, R. (1998). Human rights in history and civics textbooks: The case of Israel. Curriculum Inquiry, 28(2), 195-208.

Freire, P. (1997). Pedagogy of the oppressed. New York: Continuum. 
Gandhi, M. (1998). Postcolonial theory: A critical introduction. New York: Columbia University Press.

Gibson, N. C. (1999). Rethinking Fanon: The continuing dialogue. New York: Humanity Books.

Greeson, L. E. (1994). Torsten Husen: A case of ethnocentrism in U.S. educational research. Interchange, 25(3), 241-259.

Grieeshaber, S., \& Cannella, G. (2001). Embracing identities in early childhood education: Diversity and impossibilities. New York: Teacher College Press.

Gur-Ze'ev, I. (Ed.). (2000). Conflicting philosophies of education in Israel/Palestine. London: Kluwer Academic.

Hill, D., McLaren, P., Cole, T., \& Rikowski, G. (2002). Marxism against postmodernism in educational theory. New York: Lexington Press.

Hiner, R. N. (1978). Wars and rumors of wars: The historiography of colonial education as a case study in academic imperialism. Societas, 8(7), 89-114.

Hiner, R. N. (1990). History of education for the 1990s and beyond: The case for academic imperialism. History of Education Quarterly, 30(2), 137-160.

James, A., \& Prout, A. (1997). Constructing and reconstructing childhood. London: Falmer.

Khalidi, W. (1992). All that remains: The Palestinian villages occupied and depopulated by Israel in 1948. Washington, DC: Institute for Palestine Studies.

Lacsamana, A. E. (1998). Academic imperialism and the limits of postmodernist discourse: An examination of Nicole Constable's Maid to order in Hong Kong: Stories of Filipino workers. Amerasia Journal, 24(3), 37-42.

McLaren, P., \& Farahmandpur, R. (2001). Teaching against globalization and the new imperialism: Toward a revolutionary pedagogy. Journal of Teacher Education, 52(2), 136-150.

McLaren, P., \& Pinkney-Pastrana, J. (2000). The search for the complicit native: Epistemic, violence, historical amnesia and the anthropologist as ideologue of empire. Qualitative Studies in Education, 13(2), 163-184.

Memmi, A. (1965). The colonizer and the colonized. Boston: Beacon.

Menchù, R. (1996). Rigoberta Menchù: Growing up in Guatemala. In L. C. Mahdi, N. C. Christopher, \& M. Meade (Eds.), Crossroads: The quest for contemporary rites of passage (pp. 327-329). Chicago: Open Court Press.

Mohanty, C. T. (1994). Under Western eyes: Feminist scholarship and colonial discourses. In K. Williams \& L. Chrisman (Eds.), Colonial discourse and post-colonial theory: A reader (pp. 196-221). New York: Columbia University Press.

Mutua, K., \& Swadener, B. B. (2003). Decolonizing research in cross-cultural contexts: Critical personal narratives. Albany: State University of New York Press.

Pappe, I. (1992). The making of the Arab-Israeli conflict 1947-51. New York: St. Martin's.

Parenti, M. (1988). The sword and the dollar. New York: St. Martin's.

Parry, N. (1995). Making education illegal. West Bank, Palestine: Birzeit University.

Ram, U. (2000). National, ethnic or civic? Contesting paradigms of memory, identity and culture in Israel. Studies in Philosophy and Education, 19, 405-422.

Said, E. (1978). Orientalism. New York: Vintage.

Said, E. (1993). The politics of knowledge. In C. McCarthy \& W. Crichlow (Eds.), Race, identity, and representation in education (pp. 306-315). New York: Routledge.

Said, E. (1994). From Orientalism. In P. Williams \& L. Chrisman (Eds.), Colonial discourse and post-colonial theory: A reader (pp. 132-150). New York: Columbia University Press.

Semali, L. M., \& Kincheloe, J. L. (Eds.). (1999). What is indigenous knowledge? Voices from the academy. London: Falmer. 
Smith, L. T. (1999). Decolonizing methodologies: Research and indigenous people. New York: University of Otago Press.

Soen, D. (2002). Democracy, the Jewish-Arab cleavage and tolerance education in Israel. International Journal of Intercultural Relations, 26, 215-232.

Spivak, G. C. (1999). A critique of the postcolonial: Reason toward a history of vanishing present. Cambridge, MA: Harvard University Press.

Taiaiake, A. (1999). Peace, power, righteousness: An indigenous manifesto. London: Oxford University Press.

Janette Habashi is an assistant professor in the Department of Human Relations, University of Oklahoma. A Palestinian from the old city of Jerusalem, she was educated in Rammallah and earned a degree in social work from Bethlehem University in the West Bank. In 1992, the British Council in Jerusalem awarded her a 2-year fellowship to finish her master's degree in counseling in education. She began her doctoral program at Hebrew University then transferred to Kent State University, where she completed her Ph.D. in 2003. 